2007RP-01

\title{
The Design of an Efficient Offshoring Strategy: Some Reflections and Links to SNC-Lavalin
}

\author{
Marcel Boyer
}

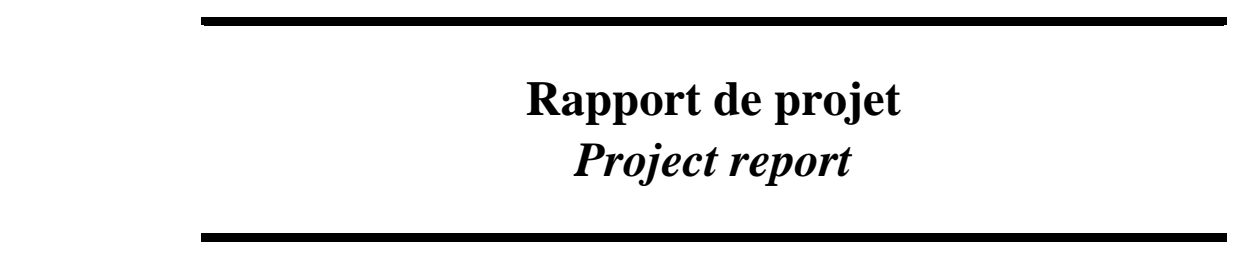

Ce rapport a été produit dans le cadre du projet « Offshoring : Issues for

Canada » financé par Industrie Canada

\author{
Montréal \\ Mars 2007
}

(c) 2007 Marcel Boyer. Tous droits réservés. All rights reserved. Reproduction partielle permise avec citation du document source, incluant la notice (C).

Short sections may be quoted without explicit permission, if full credit, including $@$ notice, is given to the source

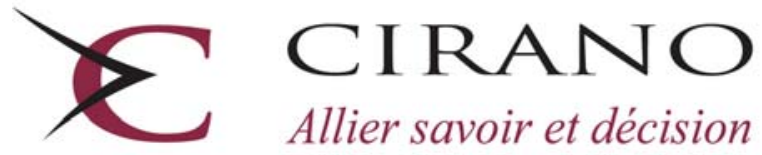

Centre interuniversitaire de recherche en analyse des organisations 


\section{CIRANO}

Le CIRANO est un organisme sans but lucratif constitué en vertu de la Loi des compagnies du Québec. Le financement de son infrastructure et de ses activités de recherche provient des cotisations de ses organisationsmembres, d'une subvention d'infrastructure du Ministère du Développement économique et régional et de la Recherche, de même que des subventions et mandats obtenus par ses équipes de recherche.

CIRANO is a private non-profit organization incorporated under the Québec Companies Act. Its infrastructure and research activities are funded through fees paid by member organizations, an infrastructure grant from the Ministère du Développement économique et régional et de la Recherche, and grants and research mandates obtained by its research teams.

\section{Les partenaires du CIRANO}

\section{Partenaire majeur}

Ministère du Développement économique, de l'Innovation et de l'Exportation

\section{Partenaires corporatifs}

\section{Alcan inc.}

Banque de développement du Canada

Banque du Canada

Banque Laurentienne du Canada

Banque Nationale du Canada

Banque Royale du Canada

Banque Scotia

Bell Canada

BMO Groupe financier

Bourse de Montréal

Caisse de dépôt et placement du Québec

DMR Conseil

Fédération des caisses Desjardins du Québec

Gaz de France

Gaz Métro

Hydro-Québec

Industrie Canada

Investissements PSP

Ministère des Finances du Québec

Raymond Chabot Grant Thornton

State Street Global Advisors

Transat A.T.

Ville de Montréal

\section{Partenaires universitaires}

École Polytechnique de Montréal

HEC Montréal

McGill University

Université Concordia

Université de Montréal

Université de Sherbrooke

Université du Québec

Université du Québec à Montréal

Université Laval

Le CIRANO collabore avec de nombreux centres et chaires de recherche universitaires dont on peut consulter la liste sur son site web.

ISSN 1499-8610 (Version imprimée) / ISSN 1499-8629 (Version en ligne)

Partenaire financier

Développement 


\title{
The Design of an Efficient Offshoring Strategy: Some Reflections and Links to SNC-Lavalin*
}

\author{
Marcel Boyer ${ }^{\dagger}$
}

\section{Résumé / Abstract}

L'objectif de ce rapport est triple : d'abord, dresser le tableau des facteurs sous-jacents au phénomène de l'impartition offshore devenu un sujet de préoccupation en politique publique; ensuite, considérer l'expérience récente d'une grande entreprise canadienne d'ingénierie (SNCLavalin) en cette matière; finalement, inférer de ces analyses, de ces données et de ce cas, des leçons pour la définition de politiques gagnantes d'offshoring.

Mots clés : impartition offshore

The objectives of this paper are threefold; First, to brush an overview of the underlying drivers of the offshoring phenomenon that have appeared on economic and public policy radar screens over the last 15 years; Second, to look at the recent offshoring experience of a large Canadian engineering firm (SNC-Lavalin) with significant international experience and exposure; Third, to draw from the analysis, the evidence and the case at hand some lessons for public policy aimed at defining winning offshoring strategies.

Keywords: Offshoring

\footnotetext{
* I am grateful to participants in the Rotman School / Industry Canada Conference "Offshore Outsourcing: Capitalizing on Lessons Learned” (Toronto, October 2006), in particular to Dan Trefler of the Rotman School (University of Toronto), Mohammed Rafiquzzaman, Someshwar Rao and Prakash Sharma of Industry Canada for their comments on earlier drafts of this paper. I am also very grateful to Jacques Lamarre, President and CEO of SNC-Lavalin, and Krish Krishnamoorthy, former Head of the firm's Chemical and Petroleum division for informal conversations. Needless to say, I bear full and sole responsibility for the content and shortcomings of this paper. Financial support of Industry Canada is gratefully acknowledged.

${ }^{\dagger}$ Bell Canada Professor of Industrial Economics, Department of Economics, Université de Montréal, CIRANO and CIREQ Fellow, CIRANO, 2020 rue University, bureau 2500, Montréal (Québec), H3A 2A5, marcel.boyer@cirano.qc.ca.
} 


\section{Introduction}

Offshore outsourcing or Offshoring refers in its general meaning to a business procurement strategy, by which foreign suppliers of goods and services are retained in order to cur costs and improve competitiveness (Brown and Wilson 2005). More specifically, the Offshoring phenomenon refers to services rather than goods and to the displacement of professional or business services jobs rather than manufacturing jobs from home country suppliers or providers (including in house procurement) to foreign ones. We consider in this paper the latter more specific definition of offshoring. But it should be clear to everyone that there is a continuum of phenomena going from internal or in house, home country production or procurement of intermediate goods and services to home country outsourcing of such procurement, to the displacement of such procurement to in house offshore (subsidiary) business units, to offshore outsourcing of such procurement to foreign suppliers and providers. However, we will constantly keep in mind the two most important specific characteristics of the offshoring phenomenon, namely that it deals with services rather than physical goods and that it implies a displacement of jobs from the home country to a foreign country rather than simply the creation of new jobs in a foreign country, although such new jobs created will be considered as offshored jobs if they could have been created in the home country instead.

The objectives of this paper are threefold; First, to brush an overview of the underlying drivers of the offshoring phenomenon that emerged and appeared on economic and public policy radar screens in the late 80s but mainly since the late 90s; Second, to look at the recent offshoring experience if not explicit strategy of a large Canadian engineering firm (SNC-Lavalin) with significant international experience and exposure as an illustration of the challenges other firms, large, medium and small, are already facing or will likely be confronted with in the near future; Third, to draw from the analysis, the evidence and the case at hand some lessons for public policy aimed at defining winning offshoring strategies. Offshoring, or more precisely offshore outsourcing of business services, is a phenomenon that emerged and appeared on economic and public policy radar screens with the significant increase in competitive pressures that resulted from mainly two phenomena: 
first, the rapid dissemination of information and communication technologies and the related movement towards deregulation in telecommunications, and second, the increasing liberalization of international trade and investment.

With the advent of these two phenomena, the globalization of services such as telecommunications, retail trade and finance first appeared. The services sector as a whole is the most directly concerned sector affected by the offshoring phenomenon. This sector, whose products were first seen as quasi non-tradable, has been transformed by the new technologies and trade liberalization. A new wave of globalization has also recently emerged with a seemingly increasing transfer of white collar and high skilled occupations offshore. These types of services which were previously seen as protected from offshoring constitute the main component of the offshoring phenomenon. From now on, professions such as engineers, medical doctors, teachers, and others, can be considered as potentially vulnerable to competition from abroad.

This paper is organized as follows. Following a section serving as a backgrounder on offshoring in part based on the one-day roundtable held at Industry Canada in March 2005, I provide in Section 3 an integrated presentation of the theoretical links between increased competition and incentives; this helps understand the different forms and shapes of offshoring strategies followed by firms. In Section 4, I very briefly discuss the new information and communications technological context to explain what these new developments, changing in significant ways our notions of time and space, mean for the organizational structures of firms. Section 5 is devoted to the analysis, in this new information and communication technological and trade liberalization context, of the usual non-changing challenges of firm, namely the design of strategies around the usual competitiveness drivers: costs, quality, and risk management, that is, in the present offshoring agenda, proper management control of offshored operations. I present in section 6, SNC-Lavalin - the firm and the potential offshoring challenges it faces or will be facing in the coming years; and in Section 7, my analytical understanding of SNC-Lavalin's operational strategy expressed along "inter-local”, outsourcing and offshoring dimensions. I provide some preliminary concluding remarks in Section 8. 


\section{A Backgrounder on Offshoring}

Table 1 from Trefler (IC Roundtable 2005; from Statistics Canada “Canada's Balance of International Payments” for 2004) illustrates in broad terms the offshoring phenomenon for Canada. We see that in 2004 commercial services accounted for about 50\% of the trade in services, that our exports of services represented about $15 \%$ of our exports of goods while our imports of services represented about $20 \%$ of our imports of goods. See also Brown and Wilson (2005, p.2-5), citing the Global Outsourcing Partnership, on offshoring trends in different industries.

\section{Table 1}

Canada's service trade and offshoring of IT and business process

\begin{tabular}{|c|c|c|c|c|c|}
\hline \multirow[b]{3}{*}{ Service Provided } & \multicolumn{2}{|c|}{ Exports } & \multicolumn{2}{|c|}{ Imports } & \multirow{3}{*}{$\begin{array}{c}\text { Net Exports } \\
\\
2004 \\
\end{array}$} \\
\hline & & Growth & & Growth & \\
\hline & 2004 & 1997-2004 & 2004 & 1997-2004 & \\
\hline Commercial Services & $\$ 32.4$ & $7 \%$ & $\$ 36.1$ & $7 \%$ & $-\$ 3.8$ \\
\hline 1. Computer and information services & $\$ 2.9$ & $8 \%$ & $\$ 1.6$ & $7 \%$ & $\$ 1.4$ \\
\hline 2. Other business services & S17.5 & $7 \%$ & S16.5 & $7 \%$ & $\$ 1.0$ \\
\hline 2.1 Non-financial commissions & $\$ 0.9$ & $3 \%$ & $\$ 0.6$ & $2 \%$ & $\$ 0.3$ \\
\hline 2.2 Equipment rentals & $\$ 0.3$ & $6 \%$ & $\$ 0,7$ & $7 \%$ & $-\$ 0.4$ \\
\hline 2.3 Management services & $\$ 3.6$ & $9 \%$ & $\$ 4.7$ & $8 \%$ & $-\$ 1.0$ \\
\hline 2.4 Advertising and related services & $\$ 0.4$ & $9 \%$ & $\$ 0.6$ & $3 \%$ & $-\$ 0.2$ \\
\hline 2.5 Research and development & $\$ 2.6$ & $6 \%$ & $\$ 1.0$ & $3 \%$ & $\$ 1.7$ \\
\hline 2.6 Architectural, engineering, other technical & $\$ 3.4$ & $4 \%$ & $\$ 1.8$ & $10 \%$ & $\$ 1.7$ \\
\hline 2.7 Miscellaneous services to business & $\$ 3.9$ & $7 \%$ & $\$ 4.7$ & $5 \%$ & $-\$ 0.8$ \\
\hline 2.8 Audio-visual services & $\$ 2.3$ & $13 \%$ & $\$ 2.5$ & $10 \%$ & $-\$ 0.1$ \\
\hline 3. Communication services & $\$ 2.3$ & $3 \%$ & $\$ 2.2$ & $3 \%$ & $\$ 0.1$ \\
\hline 4. Construction services & so.1 & $8 \%$ & $\$ 0.1$ & $-4 \%$ & $\$ 0.0$ \\
\hline 5. Insurance services & $\$ 4.6$ & $3 \%$ & $\$ 6.6$ & $4 \%$ & $-\$ 2.0$ \\
\hline 6. Other financial services & $\$ 1.5$ & $4 \%$ & $\$ 2.4$ & $6 \%$ & $-\$ 0.9$ \\
\hline 7. Royalties and licence fees & $\$ 3.3$ & $23 \%$ & $\$ 6.7$ & $13 \%$ & $-\$ 3.4$ \\
\hline Totnl, trade in services & $\$ 62.3$ & $6 \%$ & $\$ 73.5$ & $5 \%$ & $-\$ 11.2$ \\
\hline Total, trade in goods & $\mathrm{S} 430.3$ & $5 \%$ & $\$ 363.0$ & $4 \%$ & 567.3 \\
\hline
\end{tabular}

A variety of factors have increased the tradability of services over the years: 
- Trade and investments liberalization, which increased competitive pressures to minimize costs and improve productivity

- Technological advances in information and communication technologies, which made competitive pressures even more challenging

- Shortage of competencies (skills shortage) at the national level

Among those factors, globalization and trade liberalization as well as the expansion (development and adoption) of information and communication technologies (ICT) are probably the most significant factors behind the increase in competitive pressures and the rise in offshoring activity.

More precisely, it is generally understood that four specific enabling factors explain the relative and asymmetric development -- fast or slow, extensive or not -- of offshoring activity in different industries and countries: the possibility of significant cost savings through offshoring, the possibility to maintain quality standards in offshored activities, the possibility to control the risk level inherent to offshoring activities, and the possibility to ensure an effective management control over offshored activities. As these possibilities materialize, one can expect that offshoring will gain in popularity. These factors are present in one way or another in many different analytical and/or empirical or applied business and scholarly publications on offshoring. See in particular Brown and Wilson (2005), Vashistha and Vashistha (2006), Cohen and Young (2006), neoIT Inc. (2004), Robinson and Kalakota (2005). These publications contain significant empirical evidence on different facets of the offshoring phenomena in numerous industries and countries.

\section{The IC Roundtable on Offshoring (2005) ${ }^{1}$}

Industry Canada brought together in March 2005 a group of academic, labour, industry, and government economists to discuss the phenomenon of offshoring. This roundtable favoured a thorough discussion of four broad topics related to the growing offshoring

\footnotetext{
${ }^{1}$ References by author's name in this subsection refer to the presentation of those authors at the IC Roundtable; those presentations may be available from the MEPA group at IC.
} 
phenomenon: the nature and measure of the phenomenon, its explanatory factors, its impacts, and the desirable policies to address those issues.

The nature and measurement of the phenomenon

Offshore procurement, even in services, is not really a new phenomenon. It has existed for a long time and is only the prolongation of the portfolio of strategies pursued by firms in their continual search for efficiency and competitiveness, in particular those strategies directly linked to the concretization of their effective organisational limits: vertical integration, sourcing within their own internal network (insourcing), sourcing outside their internal network (outsourcing). It is the rate of its development that worries policy makers. As if one realized suddenly that the "global village" (in services) was no more simply an image and a concept but a reality, with which it will be necessary to compose effectively and quickly.

Offshoring, the phenomenon of extraterritorial procurement of goods and services but mainly of professional business services, which were at one time subject to in-house or incountry procurement, has become a subject of great concern mainly because services until very recently appeared safe from foreign competition. Indeed, exchanges in services used to require a form of proximity between supplier and demander. However, the accelerated integration and liberalization of markets and trade, the significant expansion and intensification of competitive pressures, and worldwide innovations of all kinds (technological as well as social and organizational), supported by the extraordinary development of information and communication technologies, have made the notion of "economic proximity" itself truly planetary. Hence, the phenomenal development of services in international exchanges is fast becoming a reality.

The services sector represents roughly two thirds of the gross domestic product. If it is touched the most by the offshoring phenomenon, it is because the natural barriers in trading services were significantly reduced with the advent of new information and communication technologies. Jobs, which were previously considered as untouchable, have become 
challenged by offshoring possibilities. The phenomenon is explosive because of the strong supermodularity between changes in ICT and recourse to offshore procurement in services: in the search for efficiency and productivity gains, more of one implies more of the other.

The offshoring phenomenon reaches knowledge-based jobs and competencies and, for this reason, exacerbates the problems of economic policy vis-à-vis the displacement or delocalization of economic activity. Since offshoring rests on modern technologies, among the most advanced and most dynamic ones, its development does already challenge governmental strategies of support to innovation, a central element of current policies aimed to improve and consolidate the competitiveness of Canadian firms.

There was a phenomenal growth of the offshoring phenomenon over the last ten years and the movement is not ready to stop. Firms now consider recourses to offshoring for many if not all functions: finance and accounting, product development, research and development, design and engineering, human capital management, as well as services aimed at the adoption of, adaptation to, and implementation of new technologies. The services with strong "offshorability” could account for $20 \%$ of employment within OECD (van Weslum).

Moreover, this movement could be facilitated by the fact that several foreign firms, which benefit from offshore procurement agreements with North-American firms, are in fact held entirely or partly by North-American firms (insourcing contracts between a national company and its foreign subsidiaries, or outsourcing contracts between a national firm and another national firm that transfer the contract to its foreign subsidiary). Not only profits can be repatriated but the gains in productivity and cost reduction can be very significant: transactions are carried out between close partners whose operations are realized at significant distance.

There is no specific agreed upon measurement of the offshoring phenomenon. Thus, the data that circulate on this subject are often based on anecdotic evidence and projections are sometimes made on a doubtful basis from indirect sources such as trade data, employment data, and input-output tables. It proves difficult to use and interpret these measures of 
offshoring because the data on trade in services are themselves difficult to gather, in particular regarding the share related to offshoring itself.

According to recent data (Table 1 above), Canada exported for 32 billion dollars and imported for 36 billion dollars of services in 2004. Various sources suggest that Canada is 3rd in the world among destinations of offshoring contracts. In addition, most of the offshoring originating in Canada would be destined for OECD member countries (85\%) although a share of these contracts could be transferred to other countries (re-offshoring). However, the portion assigned to non-OECD countries, in particular China and India, seems to be increasing at a fast rate. If this important growth differential were to continue, these countries could in the near future dominate the markets for offshore procurement of services.

\section{* Explanatory factors of offshoring development}

Offshoring must be understood as resulting from a diverse set of factors, of which the most important ones seem to be the following. The increase in the intensity of competition in all fields and at all levels is translated into increased pressures and needs to reduce costs. The reduction of costs may be achieved by a more important recourse to offshoring. The cost reductions make it possible for firms to generate free cash flows to increase their capital budgeting for investments in new technologies aimed to increase productivity and raise quality standards. Offshoring makes it possible for firms to better face fluctuations in workloads through multiple technological spheres and offers a solution to skills shortage at the national level. Offshoring provides more expertise and capacity and thus flexibility to firms.

The recent development of ICT translated into a dramatic reduction of their costs, to the point where they became accessible to all and thus made it possible for countries, formerly “distant”, to come closer to the main axes and networks of international exchanges. The reduction in transport costs and the improvements in logistics also support the development of offshoring. 
Thus, the recourse to offshoring is not a simple question of costs. Other factors, as important and perhaps more important ones, such as the availability of special expertise and the capacity-flexibility tandem, are often mentioned by firms. It is difficult for firms to innovate when budgets are burdened with maintenance costs of old, possibly obsolete technologies. Offshoring represents in such a context a lower cost avenue or opportunity for change and adjustment for quite a number of firms. Offshoring could make it possible for firms to improve the quality of their business (data-processing) applications, to increase productivity through better technologies (foreign providers), to obtain adequate skilled labour at the right time, and thus to transform higher fixed costs into lower variable costs.

\section{Impacts}

Several anticipated potential impacts of large scale offshoring were identified and more or less precisely measured at the IC Roundtable:

- Increase in efficiency and effectiveness and reduction in production costs.

- Possibility of job losses in the country where the recourse to offshored procurement increases, compensated by a creation of jobs in the host country.

- Greater economic efficiency and significant welfare gains, triggered by improvements in productivity and competitiveness, both in the country of origin and the host country.

- Creation of new jobs and growth opportunities in the country of origin and the host country.

The free trade agreement between Canada and the United States has increased productivity by $15 \%$ in the directly affected manufacturing firms (Trefler) as a result of strategic changes that put more emphasis on innovation. In a similar way, offshoring is likely to favour a reduction of production costs and an increase in profit margins, making it possible for firms to increase their investments in research and development as well as in advanced (flexible) manufacturing technologies. Offshoring is also likely to provide firms with a 
better access to essential factors at lower costs, which represents an additional potential source of productivity gains.

According to The McKinsey Quarterly (June 2004), the trade in services, just like the other forms of trade, could benefit largely the developed countries and could contribute significantly to increases in standards of living. By increasing productivity, offshoring increases profit margins and makes it possible for firms to invest more in advanced technologies and innovative ideas, allowing for the creation of new jobs. Experience suggests that those jobs will have on average a greater value added.

The fragmentation (chunkification) of production and value chains, as supported by increases in offshoring, raises the demand for various types of competencies. Firms seek employees having, beyond their well codified technical skills, good judgment as well as solid analytical and communication capabilities. Moreover, new jobs are likely to require more sector specific competencies and more competencies in applied information technologies. Indeed, information technology developments may be in the future more important in sectors other than the information technology sector itself (Mann).

* Desirable public policies

The offshoring phenomenon brings new problems, as much of economic policy as of political economy. It forces Canadian firms and all their stakeholders (employees, managers, shareholders, directors, suppliers, customers, and populations in the cities and areas concerned) to participate fully in the global economy, to be more aware of their overall competitiveness, and to seize the growth opportunities that the offshoring movement represents. At the same time, these developments translate into increasing demands for government interventions at several levels.

Public policies must encourage investments to enhance competitiveness by identifying appropriate incentive mechanisms to facilitate the adaptation of displaced employees. But they must be resolutely centered on the promotion of competitiveness and gains in GDP, 
absolute and per capita. The keystone seems to be the promotion of the capacity to adapt through increased flexibility of workers and employees as well as of firms themselves.

Four growth drivers, which could and should be supported by adequate public policies, appear particularly important in this new environment (Boyer 2005, 2007).

o Inventions, innovations and implementations: the systematic search for new ideas, new ways and means of production, new ways and means of organizing both at the firm level and at the social and political levels.

o Acquisition, maintenance, and adaptation of professional competencies: the need for an incentive compatible protection against an abrupt unforeseen depreciation or obsolescence of competencies to favour a culture of change when needed.

o The key role of institutions: good governance of private and public businesses, as well as static and high powered dynamic incentive schemes.

o A renewed "Canada model” combining social democracy and competition: incentive compatible social protection; maximum openness to trade; renewed efficiency and effectiveness, modularity and experimentation in the production and distribution of public and social goods and services.

In order to benefit fully from opportunities for productivity gains, efficiency enhancements and improvements in wellbeing that offshoring offers, some public policies must be reexamined or reaffirmed.

o It is necessary to avoid protectionism and remain committed to liberalization of trade in services: the economic reality of comparative advantage remains the best guide. In that vein, we should be happy with the arrival of major new trade partners such as China, India and possibly Africa. Protectionism can certainly save some short-term jobs but it is extremely likely to reduce later on both innovation and job creation of higher value added. The temptation to design policies aimed to identify and support "winners", firms or sectors, is not only likely ineffective but especially dangerous considering the serious difficulty to correct errors in the long term. 
o It is necessary to make better use of granting rights of access to our natural resources in trade negotiations insofar as access to the resources becomes an increasingly important and crucial condition of economic growth.

o It is necessary to promote better education and training of labour, centered on the capacity to take advantage of new employment opportunities. It is less the level of human capital that poses problem than its distribution by type of competencies. Lessons and conclusions from the recent IC and HRSDC conference (September 14-15 2006) on skilled labour could be useful in this context.

o It is necessary to invest in the quality of life within Canadian cities and municipalities to reaffirm and consolidate the enviable place of Canada at that level. Many firms in many industries seek the talents of those who are attracted by urban centers of quality, and locate accordingly. In the same way, we can capitalize on the Canadian model of social cohesion and inclusion and on our proximity with the United States. For those reasons, one should not hope or want to compete with China or India in what these countries can do better, more efficiently, and at lower cost but defend and promote more aggressively the "Canada" trademark and thus become significantly more efficient at "being what we are".

o It is necessary to make changes of employment, which are becoming a central preoccupation of Canadians, less painful and even attractive for most. Public policies can help workers make such transitions through incentive compatible programs. A possibility would be to implement an investment tax credit for the acquisition and maintenance of human capital. More generally, the skills challenge that Canada is facing, which is defined as the continuous improvement of the matching between competencies and needs, is mainly due to three factors:

- The presence of imperfect and incomplete information as well on the capacities of acquiring competencies as on the socioeconomic needs for those competencies; 
- The decentralized decision making process: different agents with non-congruent incentives;

- The non-diversifiable risks in acquiring and maintaining a portfolio of competencies and skills at the individual level.

Canada lacks adequate institutions and means to effectively face this skills challenge.

o It is necessary to bring our expenditures in education closer on a per capita basis to the level observed in the USA, in particular at the post-secondary level. According to Trefler, such expenditure per student in Ontario expressed as a percentage of expenditure in the United States is about 68\% at the college level and 57\% at the university level. Given the importance of higher education in the promotion of innovation and adaptation, this gap means difficult days ahead. It is necessary to design a concerted strategy to increase also the efforts in lifelong learning and training.

Policies towards the offshoring phenomenon must first aim at avoiding the value destruction that a direct and hasty response to pressures from lobby groups asking various protection measures, which are likely to lead to unjustified delay till problems become insurmountable and require abrupt and expensive reactions. It is necessary to favour the development of policies (institutions, ways and means) that will facilitate continuous adjustments and to remember that small differences can generate significant benefits:

o Canada dropped two ranks in the classification of the countries by GDP per capita between 1990 (3rd) and 2002 (5th). If Canada had maintained its 3rd place, the GDP of 2002 would have been larger by 92 billion dollars (sic!) over the observed level (Trefler).

o Offshoring can support the virtuous circle: lower cost of ICT to increase in investments in ICT to increase in the intensity coefficient of capital used, in best practices in working environments, in new products to productivity gains to lower cost of ICT (implementation). The estimated contribution of ICT investments to GDP growth is of the order of $0.3 \%$ per annum (Mann), a very significant impact. 


\section{Increased Competition and Incentives: The Theory}

Insofar as the increasing competitive pressures drive and are driven by offshoring developments, it is necessary to better understand the links between increased competitive pressures and business strategies. And insofar as increased competition, stemming from globalization and trade liberalization (including foreign investment enhanced protection) and supported by new information and communication technologies, is expected to contribute to a more efficient economy through its impact on the internal organization of firms (coordination, incentives, limits or frontiers, geo-strategy), it is useful to consider what the theory says about those links.

We concentrate here on the links between increased competition and incentives. In the context of offshoring, this translates into different types of contractual arrangements or ownership (governance: coordination and incentive mechanisms) that will or should eventually prevail in offshoring activities, between the firm or head office and its offshore contractor or offshored subsidiary (foreign direct investment). This is clearly not the only facet of the complex relationship between increased competitive pressures and business strategy. But as we shall see, it is sufficiently important to shed some significant light on the phenomenon we are concerned with here.

The globalization of national economies and the pace of technological progress increase the overall level of competition locally and globally. According to Boyer and Laffont (2003), this phenomenon has profound impacts on the respective role and structure of organizations and markets under incomplete (asymmetric; moral hazard, adverse selection) information, which is a pervasive economic problem both at the macro-organization and microorganization levels.

First, increased competition has a significant impact on the economic role of the State as a regulator of economic activities and as a provider of public and social goods and services. Demands for profound reforms of the public sector and government institutions have been 
expressed in numerous countries. Indeed, in response to increased competitive pressures, most countries have designed and begun implementing reforms aimed at increasing the performance of their public sector. In some cases, the preferred reaction to such demands has been to privatize and/or liberalize public sectors. The OECD public management service (PUMA) provides numerous examples of national policies towards such a goal. A significant example among many is the implementation of Compulsory Competitive Tendering (CCT) procedures at the municipal and regional levels in the UK. The local authorities must issue a call for tenders for an increasing array of government services before deciding whether those services will be offered by a direct municipal/regional service organization or a private sector firm under different forms of delegated management contracts with the local authorities. ${ }^{2}$ More extensive reforms, such as for instance the move from different socio-economic regimes towards a "competitive social democracy”, although voiced in some circles, ${ }^{3}$ remain outside the public policy domain. The underlying leitmotifs of this reform movement are performance, incentives and competition.

Second, increased competition has a significant impact on the pressures for efficiency at the firm level. An important literature has investigated Machlup's (1967) claim that there is no managerial slack when a firm operates in a perfectly competitive market and Leibenstein's (1966) early empirical findings from case studies supporting the common view that increasing competition reduces managerial slack. Hence, in the private sector, firms are likely to adjust their incentive schemes in response to a more competitive environment. In their review of the academic literature on the links between increased competition and the power of incentives in organizations, Boyer and Laffont (2003) regroup the main contributions according to two dimensions: the type of agency (asymmetric information) problem and the channel by which competition affects incentives, that is, the specific meaning of "increased competition." In the present context, an organization could be

\footnotetext{
${ }^{2}$ See LeGallo (1998).

${ }^{3}$ The reforms of diverse social democracy "policies" have recently been significant in England, Australia and New Zealand as well as in Scandinavian countries, among others. For a more comprehensive reform agenda, see Boyer (2007).
} 
defined as comprising a principal (either a firm or the head office of a firm) and an agent (either an offshored contractor or an offshored subsidiary).

Along the first dimension, contributions differ according to whether moral hazard or adverse selection conditions are mainly affected by increased competition. Along the second dimension, contributions differ by the channel through which greater competition affects the level of managerial slack. An increase in competitive pressures may affect incentives in an organizational principal-agent structure either through an informational effect, that is, by increasing the information of the principal about the characteristics of the agent, or through an incentive constraint effect, that is, by affecting directly the agent's incentive constraint, for example, by making it easier or more difficult for a good type to mimic a bad type agent; or through the principal's objective function effect, that is, by affect directly the value of production for the principal and consequently the value for him of creating incentives for the agent; or through the individual rationality or participation constraint effect, that is, by affecting the outside opportunities of the agent and therefore her willingness to work for the organization. We can illustrate this classification as in the following Table, where a given cell contains the main academic contributions dealing with a similar agency problem and a similar channel but dealing possibly with different institutional contexts.

\begin{tabular}{|l|l|l|}
\hline & MORAL HAZARD & ADVERSE SELECTION \\
\hline $\begin{array}{l}\text { INFORMATION } \\
\text { STRUCTURE }\end{array}$ & $\begin{array}{l}\text { Holmström (1982) } \\
\text { Hermalin (1992) }\end{array}$ & $\begin{array}{l}\text { Nalebuff \& Stiglitz (1983) } \\
\text { Shleifer (1985) } \\
\text { Boyer \& Laffont (2003; 1,2) }\end{array}$ \\
\hline $\begin{array}{l}\text { INCENTIVE } \\
\text { CONSTRAINT }\end{array}$ & $\begin{array}{l}\text { Hermalin (1992) } \\
\text { Schmidt (1997) } \\
\text { Scharf (1983) } \\
\text { Laffont \& Tirole (1993) } \\
\text { Boyer \& Laffont (2003; 3) }\end{array}$ \\
\hline $\begin{array}{l}\text { PRINCIPAL'S } \\
\text { OBJECTIVE FUNCTION }\end{array}$ & $\begin{array}{l}\text { Hermalin (1994) } \\
\text { Schmidt (1997) }\end{array}$ & Boyer \& Laffont (2003; 5,6) \\
\hline $\begin{array}{l}\text { PARTICIPATION } \\
\text { CONSTRAINT }\end{array}$ & & Boyer \& Laffont (2003; 4) \\
\hline
\end{tabular}


Boyer and Laffont (2003) characterized the effects of stronger competitive pressures on the power of incentives in an adverse selection with moral hazard context. Contrary to conventional wisdom or a first intuition, greater competitive pressures do not always call for higher power of incentives. They considered the four channels through which competition affects the power of incentives.

First, they looked at the information channel, namely the idea that more competition provides the principal, the firm or the head office of the firm, with information about the quality (efficiency, competence) of the agent, the offshore subsidiary or offshore contractor. They showed that the effect of such better information on the power of incentives may be positive or negative. If the quality of the competition signal is sufficiently high so that, following a favourable signal (a signal making it more probable that the agent is efficient, productive, and/or of high quality), the firm would drop the offshoring project if the offshore partner turns out to be of relatively low efficiency, the power of incentives increases if the agent is in fact retained and the project is realized; if it is not, then the expected power of incentives may decrease with better information. However, when the competition signal is much better, that is, becomes very informative, the expected positive impact obtains.

Second, they looked at the threat of liquidation effect and showed that the power of incentives is insensitive to local increases of this threat.

Third, they analyzed the competition in talent effect (improving the outside options of the agent, hence making the participation constraint more severe) and showed that this such increase in competition increases the power of incentives.

Fourth, they considered the emergence of competitive pressures originating from lower cost competitors and from the emergence of better substitutes, two contexts that are particularly relevant for understanding the offshoring phenomenon and firms' reactions to it. A cost reduction at competitors' plants reduces the firm's chosen power of incentives 
when the products are strategic substitutes, and increases it when they are strategic complements and the cost of capital is large. The emergence of better substitutes for the firm's products and services increases the firm's chosen power of incentives when the degree of demand substitution is relatively strong, but reduces it when the products are strategic complements and the cost of capital is large. The main reason for the ambiguous result is that the desirable change in the power of incentives is related to the level of activity, actual or intended, of the offshored subsidiary or contractor and to the interaction between effort and production level in the cost function. Depending on the nature and strength of the substitute or complement nature of the firm's product and those of competitors, greater competitive pressures from the latter may call for a reduction or an expansion of the offshored subsidiary or contractor, which determines to a large extent the desirable change in the power of incentives that the principal (head office; firm) wants to impose on his agent (offshored subsidiary; offshored contractor), following an increase in competition.

Relative performance evaluation, or competition among agents, may be used in order to exploit the valuable information (benchmarking) conveyed by the other agents' outputs regarding the effort provided by a given agent (Holmström 1982). More competition may reduce the agent's expected income, thereby generating a negative direct income effect, by which the consumption of perks or slack is reduced and effort increased (Hermalin 1992). But a more competitive environment means also better informed shareholders regarding the actions taken and efforts provided by their agent, increasing the agent's net-of-riskpremium income and generating a positive income effect in favour of less effort. The competition effect on effort exerted is therefore ambiguous in such a context. The principal may be able can infer, from observing the outputs of all agents, some information on the productivity of his agent and therefore competition allows the design of more efficient reward structures (Nalebuff and Stiglitz 1983; Shleifer 1985).

Competition between entrepreneurial firms and managerial firms makes it more difficult for managers to shirk (Hart 1983; Scharfstein 1988). In Hermalin (1994), principal-agent hierarchies compete in the same market. Weak incentives may be the best response to 
strong incentives because the value of incentives is proportional to the firm's lower expected production level. But an increase in the number of competitors generates a substitution effect along the best reply function and a strategic effect, the rivals' production being sensitive to the firm's lower cost. Hence, more competition has an ambiguous effect. Finally, in Schmidt (1997), competition affects incentives through a positive threat-ofliquidation effect, inducing the manager to work harder, and a negative profit-reduction effect making it less valuable for the principal to implement strong incentive schemes. Schmidt obtains that increased competition may increase or reduce managerial slack given the opposite signs of the two main effects identified. Moreover, increasing competition may lower managerial slack when competition is low but increase managerial slack when competition is already intense.

What does this tell us about the effect on offshoring activities of the increased level of competition due to globalization and trade liberalization under greatly improved ICT? Based on Boyer and Laffont (2003), we can predict that increased competitive pressures faced by a firm will induce it to develop its offshoring strategy (with appropriate incentive schemes imposed on the offshore partner) if indeed those competitive pressures, together with better ICT, are associated with, for example (non exhaustive list or sets of characteristics),

* significantly lower agency costs (informational effect),

* a more demanding skills challenge at home,

* the presence of lower cost competitors when the firm is competing within an industry characterized by differentiated products (for example, goodwill or reputation based; patent protected; trademark protected).

Indeed, casual empirical observations seem to corroborate such predictions as the data and cases discussed in Brown and Wilson (2005), Vashistha and Vashistha (2006), Cohen and Young (2006), neoIT Inc. (2004), and Robinson and Kalakota (2005), among others.

Lower agency costs come from better contractual arrangements, which are in good part dependent on the development and implementation of more efficient observation and/or information and communication technologies. Such technologies would or could reduce the 
cost of controlling in-house as well as offshored activities, hence contributing to better choices of inside versus outside as well as national versus foreign procurement contracting. Moreover, the availability of such technologies will be crucial in determining the foreign country of predilection.

We will come back to these considerations when discussing the SNC-Lavalin case. But before, let us now consider briefly the new ICT context, which as indicated above should be a determining factor in the decision to offshore or not and the choice of contractual arrangement as well as the preferred location of providers.

\section{The New Information and Communications Technological Context}

The development of new ICT is without any doubt a major factor having contributed to the offshoring phenomenon. These ICT have completely changed the way companies of industrial countries carry out their activities. Information and communication technologies have also opened a window of opportunities to developing countries. These technologies have given them the opportunity to be more competitive and to participate in the international markets, in particular trade in services. The fundamental reason is that overall these new ICT could reduce the cost of asymmetric information. Hence, the combination of increased competition and new ICT represents a major boost for efficiency and also for offshoring.

First of all, new technologies such as Internet, have allowed instantaneous exchange of information. Instantaneous telecommunications capacity and affordable computers have made it possible to exchange better quality information directly at significantly lower cost. By this fact, some business activities have been facilitated and many service activities are now more efficient. Service offshoring, however, has been propelled by the possibility offered by technologies to carry out some activities independently of their geographical location. With the constant pressures on cost and productivity imposed on firms, the arrival of these new technologies has been seen as an excellent opportunity to relocate some activities where costs are lower. 
On the other hand, digitalization is also an important phenomenon that has modified the service sector. The transportation of important complex documents or data (maps, designs, three-dimensional representations, videos) was previously time consuming, risky and expensive. The digitalization (together with encryption) thus facilitates the exchange of these documents quickly, around the world, without altering quality.

Service offshoring could obviously not be possible if service businesses had not adopted standardized software. In order to be able to exchange information, firms must use common software. Fortunately, the development of new technologies has also brought the development of high-performance software which has been adopted by many businesses as a way to standardize and streamline operations and improve controls. The exchange of information can then be more easily and more efficiently realized; this favours offshoring.

\section{Offshoring Strategies: Costs and Risks as the Usual Culprits}

In order to remain competitive, it is crucial for a firm to articulate its offshoring strategy around the usual competitiveness drivers: costs, quality, and risk management, that is, proper management control of offshored operations. ${ }^{4} \mathrm{~A} 2 \mathrm{x} 2$ matrix captures quite well the different management possibilities, with the ownership structure on the horizontal axis and the localisation on the vertical axis. The focus here is on the bottom cells, as globalization, liberalization and new ICT affect management possibilities and allow a real choice of management structure. Clearly, the matrix is overly simplified as other forms of ownership with different levels of management control are possible.

\footnotetext{
${ }^{4}$ Vashistha and Vashistha (2005).
} 


\begin{tabular}{|c|c|c|}
\hline & $\begin{array}{c}\text { Internalized } \\
\text { (activities performed in-house) }\end{array}$ & $\begin{array}{c}\text { Externalised (external suppliers) } \\
\text { Outsourcing }\end{array}$ \\
\hline At home & $\begin{array}{l}\text { Company performs the activities at } \\
\text { home }\end{array}$ & Suppliers in home country \\
\hline $\begin{array}{l}\text { Foreign } \\
\text { countries }\end{array}$ & $\begin{array}{l}\text { Own subsidiary in foreign country } \\
\text { Intra-firm (captive) Offshoring }\end{array}$ & $\begin{array}{l}\text { Suppliers in foreign countries } \\
\text { Offshore Outsourcing }\end{array}$ \\
\hline
\end{tabular}

Source: Pyndt and Pedersen (2006), p.12

\section{* Cost reduction}

Service businesses are significantly influenced be the cost factor when deciding to offshore some of their activities. As mentioned previously, competitive pressures to reduce costs and improve productivity force many companies to restructure and reorganize the way they perform their activities. Offshoring appears to be a good alternative for many service activities since developing nations now offer comparable services at lower cost.

The cost-influenced move to offshore some activities is first motivated by the disparity between salaries and wages. Workforce from developing nation such as India now offers a vast variety of services which is quite comparable in quality to those available in industrialized countries but at much lower costs. Thus, offshoring can give companies a major competitive advantage in terms of cost effectiveness.

Two surveys confirm that cost reduction is the main motive for offshore outsourcing. The first survey, conducted jointly by Duke University and Archstone Consulting, draws its results from 102 mostly American corporations, with different sizes. 


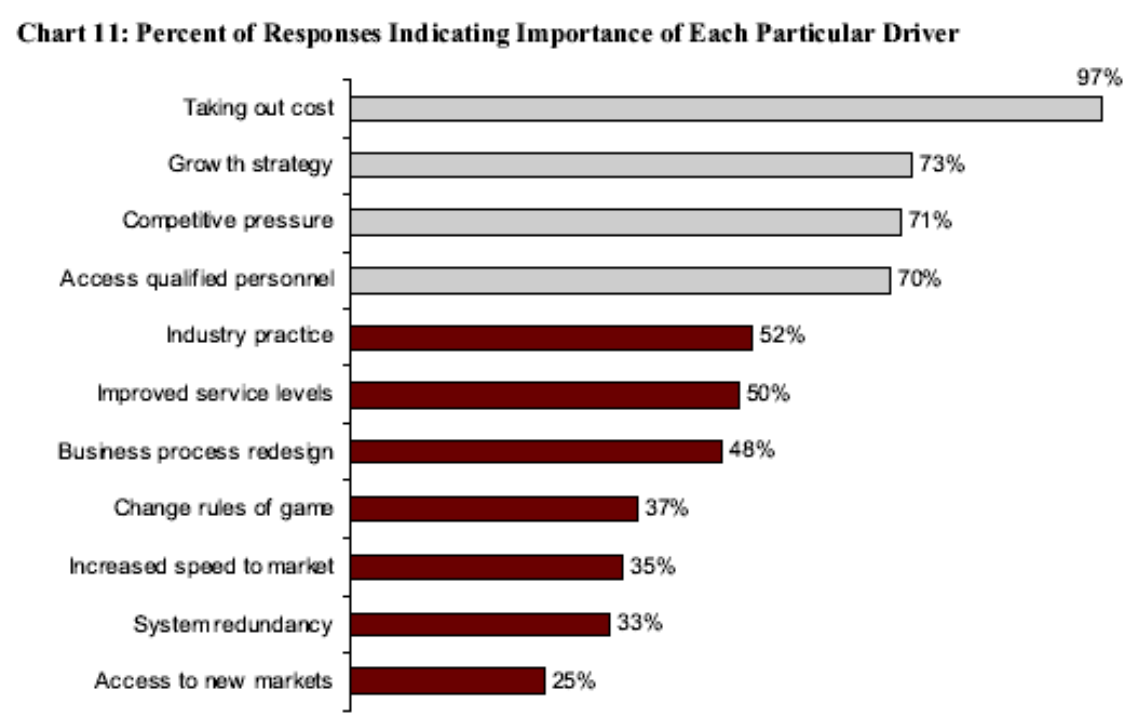

Source: Duke University CIBER/Archstone Consulting (2005)

The reason why cost is the top priority is that cost may be a convenient metric when comparing locations or providers, especially when savings can be high. Increased competition, both at local and global levels, forces a firm to reduce costs and offshore outsourcing allows the firm to achieve these goals.

The competitive pressures may be so high that one firm proceeding with offshoring is enough to drag all the others in a given industry (domino effect). Moreover, surveys may not capture the fact that companies evolving in a competitive market often tend to follow the leader and are thus more disposed to proceed to offshore operations if the leader(s) proceed with such a strategy.

Managers are thus constrained to either make better use of technologies and/or to proceed with reengineering of the labour force, two concepts that can be complementary and simultaneously feasible when the firm opts for an offshoring strategy: a possible result being higher quality goods and services at lower costs.

Priorities are similar for European companies as the survey conducted jointly by UNCTAD and Roland Berger Strategic Consultants shows. Since services are typically labour- 
intensive, this study makes a distinction between two types of costs, where labour costs should be defined as the ratio of wage over productivity.

Benefit

Reduce labour costs

Reduce other costs

Improve service quality

Focus on core activities

Speed up process cycles

React to lack of internal staff or capabilities

Extend scope of services

Strengthen own affiliate in target country

Access better technology and/or infrastructure

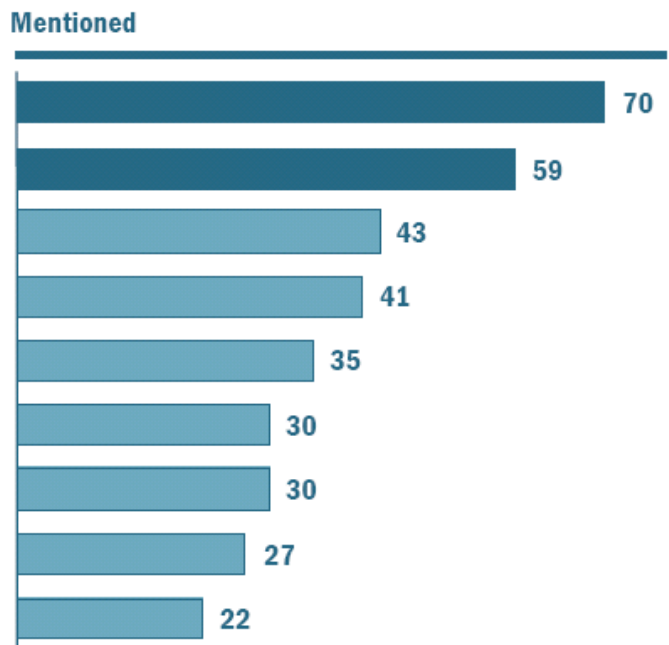

Source: UNCTAD and Roland Berger Strategic Consultants (2004)

Total costs of offshoring

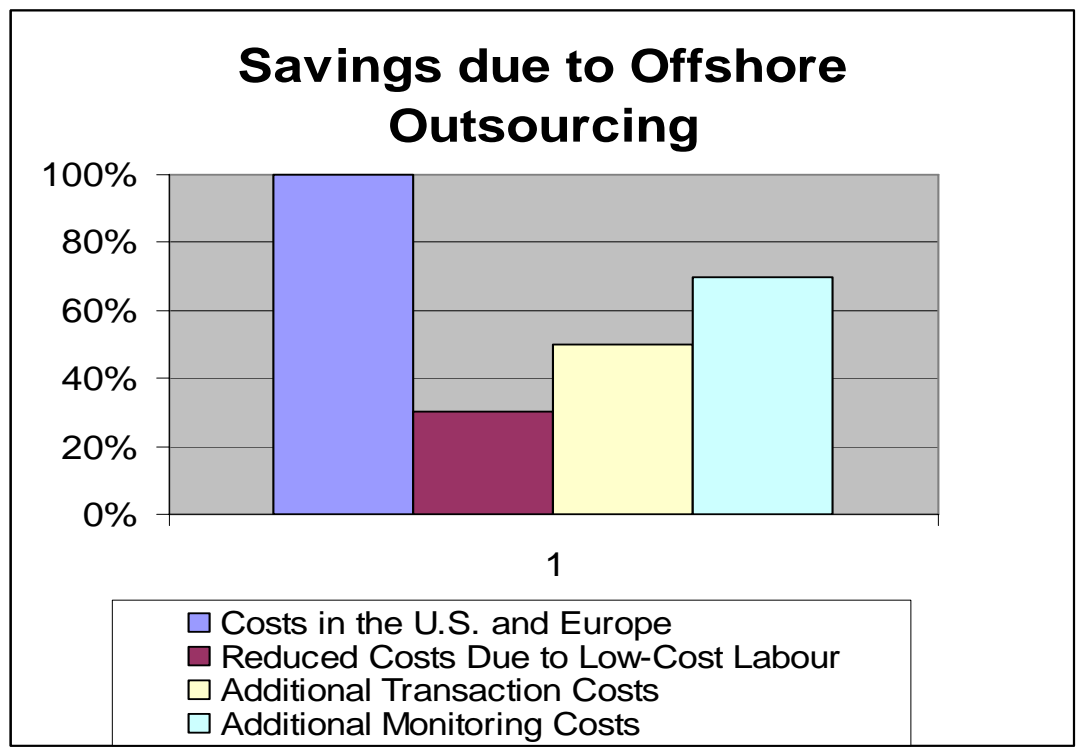

Source: Kalakota and Robinson (2004) p.17

The different categories of cost above may be more relevant for a company establishing a new internal offshore operation, for instance a captive call centre (insourcing). As for 
offshore outsourcing, some of these costs may already be incurred by the provider and included in the price charged. There are other types of costs, like searching for a suitable supplier as well as transactions cost such as negotiation and contract enforcement costs, which must be taken into account.

\section{o Lower costs and the localisation choice}

In emerging markets, the current costs and state of the labour market is not enough to consider a localisation. Clusters are expanding for some specific professions with expertise creating positive network externality effects. Despite higher costs, the benefits of investing in these clusters can overcome it.

Effectively, following the same idea, centers of excellence have been developed in order to provide distinctive skills and expertise. ${ }^{5}$ Nowadays, for most offshoring regions and professions, supply exceeds demand in the labour market, so it can ensure a reliable labour force. However, according to the McKinsey Global Institute, scarcity in the field of engineering in India will start to be felt as soon as 2010 and this could lead to an overheating market. Wage increases would then pick up, resulting in rising costs. Therefore, it is important for a manager to have a long-term focus when considering labour costs.

\section{o Steps towards an efficient offshoring strategy}

No one-fits-all model is available when developing an offshoring strategy, because of the industry or firm specificity. However, guidelines can be drawn. Before considering any cost reduction, one should evaluate the strengths and core competencies of the firm, and subsequently consider what process to offshore. In order to maintain cost-saving efficiency, one must assess the quality and quantity of the service delivered. Easily scalable (flexible) processes are preferred, leading to offshore repetitive tasks and ones that demand a lower degree of analysis. The degree of integration and the linkages of the process to the whole

\footnotetext{
${ }^{5}$ World Investment Report 2004: The Shift Towards Services, UNCTAD
} 
business model and goals should also be stressed. An evaluation should be conducted on the perspective of cost minimisation while preserving quality. The tasks to offshore must be embedded into an appropriate ownership model (captive center, joint venture or offshore outsourcing). Since a supplier can benefit of scale economies based on its specialisation, lower costs are often obtained within the latter.

\section{- Quality versus costs}

"Went for cost, stayed for quality" (Dossani and Kenney, 2004) should be a mark of success for any company. In fact, quality should be as important as the cost savings since the manager's interest is to maximise the ratio of quality over cost. However, firms may weight differently these two drivers. But as offshoring is getting more and more complex and expanding beyond the IT sector, quality gains in importance. Hence, sophisticated activities seem to be the norm nowadays, pushing up the number of niche markets and centers of excellence. The question that could be raised now is what latitude should be given to the supplier, in order for the firm to realise cost reductions and have at the same time a strong grip on the control of the offshored processes.

\section{* Risk management in offshore outsourcing}

In finance, one of the first lessons on risk is diversification of assets. In the domain of managing offshore operations, a concept emerges to reduce risk: strategic multiple sourcing. The strategy consists of dividing processes into non-overlapping activities. As seen previously, offshore allows for important cost reduction but a threat exists that vendors can get the upper hand of operations. Risks can take different forms and be tackled using different approaches. First, operational risks arise when tasks are achieved with less quality and efficiency, although not in a deliberate manner. The extent of an error-ridden task is also a useful indicator of this risk that should be more noticeable in the transitional period. Second, the supplier may have incentives to diverge from the client objectives. This opportunistic behaviour refers to strategic risks and may necessitate a closer monitoring. 


\section{o Operational risks}

In this time of digitalisation, data are essential to monitor activities internal or external to the firm. From time-control variables to the creation of metrics for quality combined with technological improvements in telecommunications have propelled the offshoring perspectives along with lower operational risks. The capacity to follow the progress of operations and communicating from a long distance enables the client to react quickly and provide support for tasks or sub-tasks that lack in quality. Some problems are transitional and will tend to disappear as the new staff ascends the learning curve. Although this type of risk does not arise from a deviant behaviour, the complexity of operations may not allow its complete elimination. Other factors such as the geographical separation between the client and the supplier, cultural gap or limitations of the communication transmission system may as well create delays in the completion of work.

Codification remains the most effective approach to tackle operational risk. Monitoring will then be improved and the vendor/provider should assimilate its tasks faster. Moreover, the creation of quality metrics, even if scalability of some activities may be difficult, makes the comparison possible with the activity performed internally. Formation of standards such as the determination of weekly and monthly objectives could then be inserted in the offshore contract. Finally, it should be noted that the complexity of measuring a process is positively related to its level of operational risk.

\section{o Structural risks}

In a competitive environment, managers may feel the urge to make an offshore decision but they may not be aware of the dangers of communicating flows of information. It should be expected that unethical behaviour may come from providers, hence safeguards are required. Furthermore, a general principal-agent problem emerges as the provider's objectives could differ from those of the client firm initiating the offshoring call. For instance, the provider 
may ensure only the minimal quality standards or worse, may engage in shirking at a significant level. At an employee level, it may mean that less effort than expected will be exerted; at the organisation level, it could mean less training than planned and/or fewer resources, earmarked for the service to be provided, than agreed upon, translating into lower quality, delays, etc.

There is also a time perspective to this problem. Generally, shirking might be more prevalent at the end of a contract, or when the provider is highly reliable for the client. The detection of some of these problems is difficult, owing to a lack of information and to the time lag before observations may become clear. A second affliction that the client may have to handle is poaching. In this case, increased manipulation of information has perverse effects, since the vendor could exchange information with a competitor. In emerging markets, intellectual property rights are not always properly enforced. Once more, detection is problematic. For some activities, an expertise can be developed and then be transferred to competitors at a lower price than the one paid by the client.

Bargaining power in future contract negotiations can also be gained by vendors as an increased amount of information is given in cumulated offshore contracts. This problem is part of the last category of structural risks, namely opportunistic renegotiation. Relying on only one provider may allow the provider to have the big end of the stick, especially if transferring (repatriation) activities internally is hard. This problem is designated in the literature as hold-up by the vendor.

\section{o Risk management and strategic multiple sourcing (chunkification)}

Contractual features are fundamental tools to manage risks, both operational and strategic. However, this is not enough; a manager could decide to move back the activity internally if he feels that the process is too risky, because of the confidentiality of information for instance. Close monitoring by reviewing the entire job done offshore can be very effective but it is rather expensive. A strategic approach for clerical tasks where the errors can be 
easily assessed would be to randomly check the task, and if the number of errors exceeds a certain percentage formerly agreed on, the supplier would be penalised.

Other strategies lie in the domain of strategic multiple sourcing, where tasks can be allocated horizontally or vertically to different providers. In both perspectives, the client wants to limit knowledge transfer so that poaching would be restrained. For the horizontal strategic multiple sourcing, the objective is to force the providers to enhance their productivity in both short and long terms: such a strategy is often associated with Toyota and Bank of America, with at least two different providers performing similar activities. Both providers know that the work is totally transferable at any time, so they have incentives to perform well. If multiple sourcing seems to cut down strategic risk, it is illadvised to divide up the work among too many suppliers, since that would result in significant coordination costs and greater risk of operational errors.

As for vertical strategic multiple sourcing, it consists in reducing the risk of poaching by attributing to different providers sequential non-overlapping activities. This approach reduces risk because information is not concentrated into the hands of one provider/supplier.

\section{SNC-Lavalin: The Firm and its Offshoring Challenges}

SNC-Lavalin, established since 1911 and made public in 1986, is an industry leader in engineering and construction and a key player in the ownership and management of infrastructures. It has worldwide project experience with on-going projects in over 100 countries. Its international network has been established for over 40 years, with operating offices across Canada and in some 30 countries. The firm has a highly skilled and flexible labour force.

SNC-Lavalin's business strategy revolves around four pillars: build on recognized technical expertise in selected industry sectors, use financing capabilities to enhance competitiveness for major projects, combine technical expertise and financing capabilities 
to develop and acquire infrastructure concessions with solid fundamentals and potential, use well-established international marketing network to identify opportunities.

The firm is built around nine industry segments:

Power: Expertise includes designing, building and operating power facilities on a cost-plus reimbursable or lump sum turnkey basis; areas of activity include hydroelectric, nuclear and thermal power generation, transmission and distribution projects, energy control systems and training.

* Infrastructure and Environment: In the infrastructures sub-segment, expertise includes airports, bridges, buildings, container ports, ferry terminals, flood control systems, hospitals, mass transit systems, railways, roads and water treatment and distribution facilities; in the environment sub-segment, expertise includes environmental impact assessments and studies; site assessment, remediation and reclamation; ecological and human health risk assessment; waste management, water and wastewater.

* Chemicals and Petroleum: Expertise includes gas processing; heavy and conventional oil production; onshore and offshore oil and gas; liquefied natural gas; pipelines, terminals and pump stations; refining and upgrading; bitumen production; petrochemicals; chemicals and fertilizers.

* Mining and Metallurgy: Expertise includes a full range of services - engineering, procurement, construction and management services - in the fields of mining, mineral processing, pyrometallurgy, hydrometallurgy, electrometallurgy and mine reclamation, as well as aluminium industry projects.

* Operations and Maintenance: Expertise includes operations, maintenance, logistics and commissioning, as well as real estate and asset lifecycle management, for buildings, ships, remote sites, and military, commercial, industrial and infrastructure installations.

* Defence: Expertise includes, through SNC TEC, the manufacturing of ammunition, related propellants and propulsive powder for military and paramilitary markets. SNC-Lavalin sold its subsidiary SNC TEC in February 2006. 
Infrastructure and Concession Investments: Expertise includes equity investments since the mid-1980s, expertise to design, build, own, operate and maintain infrastructure facilities and systems, as well as to provide a financing component for them. The investments include SNC-Lavalin's interest in AltaLink L.P., Astoria Project Partners LLC, Gazmont Limited Partnership, InTransit BC L.P., Malta International Airport p.l.c., Murraylink Transmission Company Pty. Ltd., Okanagan Lake Concession L.P., Southern Electric Power Company Limited, Trencap Limited Partnership, and West End Dam Associates. Recent developments include:

o In June 2005, Okanagan Lake Concession L.P., wholly-owned by SNCLavalin, signed a 30-year concession agreement for the new William R. Bennett Bridge in Kelowna, British Columbia and concurrently awarded a \$144.5 million engineering, procurement and construction (“EPC”) contract, as well as an Operations and Maintenance (“O\&M”) contract, to two separate subsidiaries of SNC-Lavalin.

o In August 2005, Intransit BC L.P., in which SNC-Lavalin holds a 33.3\% interest, signed a 35-year concession agreement for the Canada Line, previously the Richmond-Airport-Vancouver ("RAV”) rapid transit line, in British Columbia, and concurrently awarded a \$1.6 billion EPC contract, as well as an O\&M contract, to two separate subsidiaries of SNC-Lavalin.

o In October 2005, SNC-Lavalin entered into an agreement to increase its participation in AltaLink from 50\% to $76.92 \%$, subject to regulatory approval by the Alberta Energy and Utilities Board.

o In 2005, SNC-Lavalin completed the acquisition of six engineering-related firms: BHA, Devonyx 2K Inc. and Morrow Environmental Consultants Inc., in Canada; B2000 Ingénierie S.A.S. and SIRR Ingénierie S.A.S., in Alsace, France; and RJ Associates (Engineers) Private Limited, in Mumbai, India.

* Highway 407: This segment represents SNC-Lavalin's proportionate share of 407 International Inc. The principal business of 407 International Inc. is the ownership of 407 ETR, and through 407 ETR, the operation, maintenance and management of highway 407 in the Greater Toronto area.

* Other segments: 
o Agrifood: Expertise includes food processing, packaging, handling, distribution and storage facilities for companies of all sizes in their domestic markets and internationally.

o Pharmaceuticals and Biotechnology: Expertise includes full service solutions for the pharmaceutical, biotechnology and life sciences sectors, including expertise in biotechnology and pharmaceutical process engineering, construction and validation, and regulatory compliance.

o Industrial: Expertise includes light industrial and secondary processing sectors such as glass, biofuels, lubricants, automobile and aircraft assembly, cosmetics, filling and packaging lines, process development and design, plant commissioning and start up, as well as the instrumentation and automation of industrial processes.

o Project Financing: Expertise includes, through SNC-Lavalin Capital, an accredited International Financial Centre with offices in Vancouver, Toronto, Montreal, Amsterdam and Algiers, with financial experts arranging financing for own projects and third party clients.

The following Table presents some data on SNC-Lavalin revenues for 2005. Revenues are broken down in three different ways: first by category or activity, then by industry segment and by geographic segment. Categories are defined as follows.

* Services revenues are generated by providing professional services, including engineering, feasibility studies, planning, detailed design, contractor evaluation and selection, construction management and commissioning, and are derived from costplus reimbursable contracts and fixed-fee contracts.

* Packages revenues, in which SNC-Lavalin also undertakes procurement and/or construction activities, are mainly generated from fixed-price contracts.

* Concessions revenues represent SNC-Lavalin's activities from Infrastructure Concession Investments together with operations and maintenance services, the manufacturing of ammunition and other concession-type arrangements, all of which generate recurring revenues on a long-term basis. 
SNC-Lavalin 2005 Revenues (in millions of \$C)

Total: \$ 3,787

by category

\begin{tabular}{|c|r|r|}
\hline Services & 959 & $25,3 \%$ \\
\hline Packages & 1,704 & $45,0 \%$ \\
\hline Concessions & 1,125 & $29,7 \%$ \\
\hline
\end{tabular}

by industry segment

\begin{tabular}{|c|r|r|}
\hline Power & 879 & $23,2 \%$ \\
\hline Infrastructure and Environment & 827 & $21,8 \%$ \\
\hline Chemicals and Petroleum & 579 & $15,3 \%$ \\
\hline Mining and Metallurgy & 223 & $5,9 \%$ \\
\hline Operations and Maintenance & 686 & $18,1 \%$ \\
\hline Defence & 337 & $\mathbf{8 , 9} \%$ \\
\hline Infrastructure Concession Investments & 22 & $\mathbf{0 , 6} \%$ \\
\hline Highway 407 & 70 & $1,9 \%$ \\
\hline All Others & 165 & $4,4 \%$ \\
\hline
\end{tabular}

by geographic segment

\begin{tabular}{|c|r|r|}
\hline Canada & 2,030 & $53,6 \%$ \\
\hline Africa & 504 & $13,3 \%$ \\
\hline United States & 365 & $\mathbf{9 , 6} \%$ \\
\hline Europe & 302 & $\mathbf{8 , 0} \%$ \\
\hline Asia & 198 & $5,2 \%$ \\
\hline Latin America & 118 & $3,1 \%$ \\
\hline Other & 271 & $7,2 \%$ \\
\hline
\end{tabular}

Source: SNC-Lavalin, Annual Report 2005 


\section{Engineering and Offshoring}

In order to understand the potential effect of offshoring on engineering jobs, it is necessary to understand and look at the nature of engineering activities. First of all, jobs in the engineering services sector which are the most vulnerable to offshoring are often characterized by the following attributes:

- No direct contact with customers

- High information content

- Reputation capital not crucial

- Work process is telecommutable and internet enabled

- High wage differential with similar occupation in destination country

- Low setup barriers

- Low social networking requirement

Figure 1 gives an overview of engineering services in Canada.

\section{Figure 1}

Revenue by type of engineering services in Canada, 1998

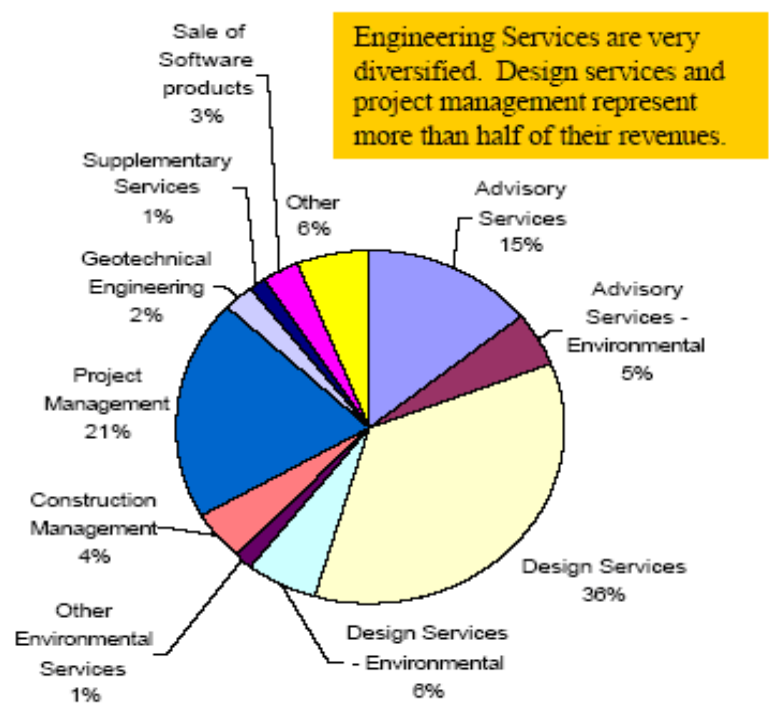

Source: Statistics Canada survey of engineering services, 1998 
Engineering works can be seen as an iterative process composed of different steps such as design, construction and evaluation where skills and expertise take great importance. From this definition, it can be seen that many factors tend to limit the type of engineering activities that can be offshored. Engineering work often requires proximity and specific expertise which are impossible to obtain when work is performed offshore. However, other types of activities performed by engineers such as design tasks could be good candidate to offshoring. In light of the above, what are the challenges the different components of SNCLavalin are facing.

\section{Offshoring Challenges for SNC-Lavalin}

SNC-Lavalin provides a large variety of engineering services which could, in part, be offshored. We will describe here the seven main types of business services offered by the company. Even if this classification of SNC-Lavalin's activities is somewhat arbitrary considering the large variety of services offered by the company, this classification is based on the different types of engineering services which can be found on the market.

\section{* Project management}

Project management activities can be described as defining and achieving target while optimizing the use of resources such as time, money, materials and people over the duration of the project. SNC-Lavalin's project management service implies its participation in all the steps of the project, from project planning to project completion.

Project management services offered by the company are composed of several types of activities:

o Planning of work and production of project schedules

o Estimating resources needed (workforce, materials, licenses)

o Organizing the work in the most efficient way

o Acquiring human and material resources

o Assigning tasks to different groups of workers 
o Directing activities in the most effective way

o Controlling the project execution

o Reporting progress

The responsibilities of SNC-Lavalin's engineers in project management are to maintain the progress and the productive mutual interaction of various parties in such a way that the overall risk of failure is reduced. Risks in project management are of various kinds including cost overrun and project delay.

SNC-Lavalin has provided these kinds of services for many decades and manages projects of every size and complexity. The expertise of SNC-Lavalin is built on some efficient project management technologies, including an interactive project management software system, called $\mathrm{PM}+$, which allows authorized parties, both on-site and with remote access, to a cumulative database of project information. The company also owns world-class project management tools designed to enhance partnering capabilities aimed to meet cost objectives and schedule goals.

\section{Project:}

Bagré Water Resources and Agricultural Development Project - Burkina Faso

Service provided: Project management

SNC-Lavalin, in association with a Belgian firm, was retained to develop the water and agricultural potential of an irrigated area of 2,100 hectares near Bagré, Burkina Faso. The total value of the services is CAN $\$ 6.6$ million financed by the African Development Bank. The services include:

- Studies and designs

- Tender and construction documents and drawings

- Coordinate tendering process and assist the client in selection of contractors

- Overall supervision of the construction works, and

- Preparation and implementation of operation and maintenance manuals and systems 


\section{o Offshoring challenges for project management}

Project management includes a vast variety of activities which are usually performed by one or many project managers. In the first part of a project, management activities do not always require the physical presence of the manager. Tasks such as planning and estimation can be done easily without being at proximity of the construction site because all the information necessary are normally included in the description of the project or can be transmitted through information and communication technologies. However, all the others tasks such as the organization of the work as well as all the monitoring activities cannot be executed if the manager is not on-site. Considering these facts, project management does not seem to be a good candidate for offshoring.

However, it is possible for engineering companies to hire the services of independent project managers for the duration of the project instead of having their own project managers. In this case, the independent project manager can come from anywhere around the world and work with the company only for the duration of the project. Local project managers can thus be in global competition with managers from developing countries.

\section{* Design services}

Design services are also part of SCN-Lavalin activities. SCN-Lavalin possesses a broad range of technical skills and resources, which allow it to offer design services in Agrifood, biopharmaceuticals, healthcare and mass transit sectors among others.

Design activities include tasks such as the generation of concept, drawing development, and design evaluation. SNC-Lavalin also has a large expertise in process engineering which focuses on the design of chemical, biopharmaceutical and industrial processes. Its principal activities include the preparation of process flow diagram, the development of circulation strategies, process analysis and optimization and finally process and facility automation. 
This work is also different from other types of engineering work because of the uniqueness of each project in terms of technical expertise and also because of the specific characteristics of projects locations. First, design activities require a vast expertise of different design software. Second, the design engineer must understand the location characteristics of the project such as the climate, the type of soil and the setting in order to produce adequate designs.

Design services include many responsibilities and the compliance to a large variety of standards and regulations is often necessary. For theses reasons, design works performed by SNC-Lavalin usually requires the signature and seal of a professional engineer. The vast majority of this work usually falls under the engineering of structures such as bridges, roads, buildings and tunnels.

\section{Project: \\ 57 km Water Transmission Line from Collingwood to Alliston}

Services Provided: Conceptual and functional design, engineering, procurement, testing and commissioning

SNC-Lavalin Engineers and Constructors (SLE\&C), a subsidiary of SNC-Lavalin Inc., as the principal in a 50/50 partnership with Con-Drain Co. Ltd., entered into a public-private sector partnership with the Town of New Tecumseth to design, build, maintain, operate and partially finance a water transmission line from Collingwood to Alliston, Ontario. Treated water is pumped from Raglan St. Pump House operated by Collingwood Public Utilities Corp. (CPUC) in Georgian Bay.

The project includes the design and construction of the 57-km, 600-mm diameter watermain, two pumping stations, three metering diameter and a chlorination plant. The pipeline is fully automated and is controlled from a central station. It was put into operation in September 1999 to meet the water supply needs of the town, specifically those of the Alliston industrial area and a Honda plant, as well as the increasing demand for water in surrounding communities.

\section{o Offshoring challenges for design services}

Design services are composed of many activities of different nature and implication in terms of responsibilities and expertise. Offshoring of design services will possibly be seen 
for more general and technical activities but will be less suitable for tasks involving high responsibilities.

Some kinds of design works requires specific knowledge about the characteristic of the project or requires on-site investigation in order to develop an appropriate design. These kinds of tasks, where the engineer must be in contact with the client or must be physically present, won't be good candidate for offshoring. In addition, design services often require the signature of a licensed engineer. Since the standards required to obtain an engineering license are different in each country, the design engineer must possess the appropriate license according to the location of the project in order to be authorized to sign the work. So these strict requirements decrease the numbers of activities that can be done by offshore engineers.

However, other design activities such as the drawing development do not require the physical presence of the designer and don't necessarily have to be realized by a licensed engineer. The designer usually possesses all the necessary information in order to create the sketch and usually uses standardized software. Offshoring these activities can be made easily. The evaluation and authorization of these sketches can thereafter be completed by a licensed engineer.

\section{* Construction}

SNC-Lavalin is internationally active in the construction industry. The company possesses many different groups throughout the world who are specialized in many areas. Those groups provide construction services in many sectors such as power, chemicals, petroleum, mass transit, mining and metallurgy.

Construction services offered by SNC-Lavalin include different activities such as: preliminary preparation of the project location, construction of structure and infrastructure, and land settlement. In order to respond to a diversified demand in terms of construction, SNC-Lavalin is composed of multiple groups working in different sectors. These groups 
have a large expertise and are able to build infrastructures that respond to the client's specific needs.

The infrastructure division of SNC-Lavalin has worldwide construction projects of many kinds. This group offers a variety of possibilities from small to large sized business, public or private enterprises and government organizations. These services include building, renovation and expansion of institutional, industrial and commercial buildings, hospitals and health centers, multifunctional complexes, industrial plants, warehouses, office and residential buildings, amphitheatres, sports facilities and transportation infrastructure. All theses projects, through the years, have made SNC-Lavalin one of the most respectable builders of the world.

Another group is working in the energy sector. The Power group, as it is called, is recognized internationally as a leader in engineering and construction of hydroelectric facilities and nuclear and thermal power plant. This division has rehabilitated and upgraded over 50 hydroelectric developments. Its rehabilitation expertise includes refurbishment of electrical and mechanical equipment, upgrading operations, optimization, life extension, flood safety and solving problems caused by alkali-aggregate reaction.

For its part, the SNC-Lavalin's Mass Transit Group specializes in the efficient, costeffective delivery of rail-based rapid transit projects, particularly light rail, conventional heavy rail and advanced automated systems. Finally, SNC-Lavalin Inc. is also a leader in the provision of a full spectrum of engineering and construction services for the mining industry.

\section{Project: \\ Ajman General Hospital - United Arab Emirates}

\section{Service provided: Construction}

SNC-Lavalin was mandated by Abu-Dhabi to build a 200-bed hospital in Ajman, United Arab Emirates. The two-storey, 15,000 m2 hospital houses five operating rooms, an emergency room, a radiology unit, a burn patients centre and intensive care unit, as well as laboratories and offices. 


\section{o Offshoring challenges for construction services}

Construction services are similar to project management services because all the work needs to be done on-site. Civil and construction engineers should not be affected by offshoring as much as others, considering the nature of their work. Given the importance of the construction industry in the major industrialized countries but also the specific demands for customized construction, offshoring is difficult to apply with these kinds of services.

Another natural limit to the offshoring of construction services is the difficulty to send an engineer to work overseas as this type of work requires site supervision and constant modifications. The construction process requires the constant supervision of the engineer and no potential lack of control can be tolerated.

\section{* Advisory services}

SNC-Lavalin has been active in consulting services for many years. Its expertise in a large variety of sectors allows SNC-Lavalin to provide advices but also technical support and professional assistance to its clients. Advisory services include many activities from on-site investigation to general implementation or construction advices.

SNC-Lavalin's consulting services are really vast and some of the main activities include:

o Undertaking technical and feasibility studies and on-site investigation and technical audit

o Resolving design and development problems

o Reviewing and approving project drawings

o Performing environmental and geotechnical analysis

o Making recommendations

SNC-Lavalin provides consulting services on many levels. These advices can thus vary from small technical details to a complete project research or analysis. 


\section{Project: \\ Water Resource and Agricultural Development Projects}

Services Provided: Technical advisory services, Project management and procurement

The mandate is to improve the rural population's standard of living in three Venezuelan states: Zulia, Trujillo and Cojedes. To be carried out in three separate projects. The main components of each project are:

- Preparation of a comprehensive master plan for the development of water, agricultural and agro-industrial resources in the project areas (geographic information, system implementation, water resource planning, comprehensive hydro geological studies and investigations, environmental impact, etc.)

- Preparation of designs and feasibility studies encompassing the technical, social, economic and financial aspects of new and rehabilitated irrigated agriculture projects based on surface and groundwater sources

- Establishment of pilot farms

- Procurement of equipment

o Offshoring challenges for advisory services

Consulting services offered by SNC-Lavalin can be divided in two broad categories. First, there are advisory services that necessitate a direct interrelation with the clients. In these cases, offshoring is not possible because the quality of these services is directly related to the exchange between the company and the clients. Also, advisory services often require on-site investigation and technical audit which cannot be done from overseas.

The other category of consulting services includes services such as approving sketches and making recommendations on specific problems. Because such kind of services implies no direct contact with customers and usually require low networking requirement, offshoring is possible.

However, advisory services are so diversified that offshoring can possibly increase the complexity of the service. So offshoring can be done according to the kind of consulting services the company wants to offer. 


\section{Construction management}

Another management service offered by SNC-Lavalin is construction management. SNCLavalin possesses skilled construction managers who can supervise construction projects entirely or can oversee only a specific part of the project.

Services offered by SNC-Lavalin in construction management consist of the planning and the coordination of construction projects, including commercial and industrial structure, nuclear and thermal power plant, healthcare, and water infrastructures. In construction management, SNC-Lavalin engineers play no direct role in the construction. The service rather consists of scheduling, coordinating and supervising the construction processes from the site preparation to the final construction.

Given the designs of the infrastructures, SCN-Lavalin supervises the planning and the implementation of the project in order to respect the different standards of quality. These construction managers work directly with designers, architects, owners and other associates of the construction project in order to guarantee the compliance to specific design technicality.

SNC-Lavalin can also evaluate and help determine the proper construction delivery systems and the most effective plan and schedule for completing the project. The objective of the project manager is then to make sure the project gets done in time and within the budget. The service also includes the determination of labor requirement and selection of contractors and workforce.

Monitoring activities is finally a major part of construction management. These activities consist of direct control of contractors and workers but also the control of materials and equipments, the quality of construction and the safety of the construction site. 


\section{Project: \\ Billiton's Mozal 250,000 t/a Greenfield Aluminum Smelter}

Services Provided: Project management, engineering, procurement and construction management (joint venture)

In 1997, Mozal S.A.R.L. awarded SNC-Lavalin, in joint venture with Engineering Management Services (EMS) of South Africa, the project management, engineering, procurement and construction management of the CAN\$1.6 billion Mozal aluminum smelter in Maputo, Mozambique.

The 250,000 ton-per-annum Mozal smelter, which represents the largest private sector investment in Mozambique, was completed in 2000. The project employed a workforce that peaked at 9000. The smelter uses Pechiney's AP30 technology.

The Mozal project was an outstanding success. It was completed six months ahead of schedule, and US\$100 million under budget, and had an excellent safety record. In recognition of these achievements in project management, SNC-Lavalin and its partner, Murray \& Roberts, were awarded the Project Management Institute's Project of the Year Award for 2001.

\section{o Offshoring challenges for construction management}

Construction management services require the constant presence of one or many construction managers. The construction manager needs to be in continuous relation with everyone working on the project. Indeed, the construction manager must coordinate on a daily basis the construction activities but also the works performed by its own workers and by different contractor at the same time. These activities cannot be done if the manager is not on-site. Also, construction management services imply a large part of monitoring activities which make offshoring almost impracticable.

\section{$\underline{\text { Supplementary services (Financial services) }}$}

SNC-Lavalin also offers many financial, risk and insurance services which allow the company to offer a complete range of services to its clients. First, SNC-Lavalin Capital group offers project financing and financial modeling services for small to large scale projects. These specialists can provide integrated financial and economic modeling services. They also possess extensive knowledge of export credit systems, have the ability 
to arrange sophisticated leverage leasing structures and are experienced in corporate financing and merger and acquisition. SNC-Lavalin Capital is also an expert in the development and the negotiation of limited recourse financing packages for concession and public-private partnership in Canada and abroad.

On the other hand, SNC-Lavalin Investment group develops and manages SNC-Lavalin's investment in companies undertaking concession or build-own-transfer project. The group participates in a variety of economic aspect of projects such as feasibility studies and they take part in the negotiating process of legal agreements such as purchase, loan and supply agreements. It also prepares financial models and analysis, performs due diligence processes and manages invested assets.

Finally, SNC-Lavalin Risk \& Insurance group is responsible for the implementation of financial protection mechanisms. Their services include the development of risk assessment and risk control techniques and also the development of efficient tools to access the insurance market. Their expertise also reaches financial risk management and control.

\section{Project: Cojedes Water Project}

Services provided : Advisor and arranger

Financing for local and foreign costs was arranged by SNC-Lavalin Capital through the Export Development Corporation (EDC) of Canada and Paribas Bank US with participation from Standard Chartered of the Bank and Fortis Bank, and partial support from the Export-Import Bank of the United States. Closing took place in late 1999.

The project involves the provision of goods and services for a comprehensive conservation and water management program in the Cojedes River Basin. 
o Offshoring challenges for supplementary services (financial services)

The supplementary services offered by SNC-Lavalin are in large part related to financial services. These kinds of services possess in most part all the attributes of jobs that are vulnerable to offshoring. First, financial data and documents can easily be communicated and transfer using information and telecommunication technologies. Second, tasks such as the development of risk control techniques or the preparation of financial analysis can be executed offshore at lower cost. Finally, many financial services do not require having a direct relationship with customers. In fact, offshoring of financial services is common in the services sectors. Even if SNC-Lavalin's financial services are more specialized than those that are usually performed by other companies, they could possibly be executed offshore.

\section{* Others}

Geotechnical engineering services are also offered by SNC-Lavalin. These services involve the interrelationship between the geological environment and the engineering works. Geotechnical services offered by SNC-Lavalin include site investigation and characterization, rock mechanics, marine geotechnics, and terrain analysis. SNC-Lavalin provides advices to government agencies for the harmonization of industrial, mining, power, and infrastructure projects with the environment in which they are developed.

The services offered by SNC-Lavalin are in majority connected to the engineering and construction field. But, in addition to the technical services such as construction and design, SNC-Lavalin also offers development and training services for executives of private and public sector but also for managers and the employees working in the mining and metallurgical sector, the industrial sector, the construction and the energy sectors.

The expertise of SNC-Lavalin is very extensive in these fields. Some of these activities of formation and development can be enumerated as follow: knowledge transfer, skill development, personnel training, on-the job training, quality management, and recruitment. 


\section{Project: \\ Integrated Soil and Water Improvement Project - Egypt}

Service provided: Other

Our mandate was to secure and increase food production by eliminating or minimizing agricultural constraints. The project was initiated in 1987 with a total value of $\$ 72.3$ millions and was accomplished in a 35,000 ha area in the eastern delta of the Nile River by:

- Implementing measures to reverse deteriorating soil conditions and to control soil salinity and water tables;

- Improving irrigation water supply management, and;

- Facilitating the adoption by farmers of improved agricultural practices.

This project demonstrated the benefits of an integrated approach to land and water management from data collection to technology transfer, including the establishment of water user associations.

o Offshoring challenges for other services

In general, offshoring of core activities or of tasks with high complexity levels remains less attractive because of issues such as security. The decision to offshore some activities can then depends on many factors which have been developed previously.

SNC-Lavalin performs many other activities. Engineering services are well diversified and evidently the above seven lines of business cannot include every type of services offered by SNC-Lavalin. 


\section{SNC-Lavalin: “Inter-local”, Outsourcing and Offshoring Strategy}

SNC-Lavalin is a Canadian firm with extensive international operations. As mentioned before, it has on any given year on-going projects in about 100 countries. Most of those projects are realized in collaboration and sometimes partnership with local firms and other international firms, engineering firms and other firms. They always make use of local/regional (host country's) resources (labour, equipment, materials, etc.). Quite often, they also make use of resources (labour, equipment, materials, etc.) from third-party countries (or regions), that is, from countries other than the host country and Canada. That is what I refer to here as an "inter-local” strategy.

The reasons for such a strategy are quite simple, straightforward, and well-known. They fall under two headings: political economy imperatives such as host's political/contractual pressures (those can be considered as project design constraints), but also efficiency and effectiveness considerations in procurement. Efficiency considerations refer to more or less stringent requirements to meet the project's goals and objectives in terms of pre-determined “productive” characteristics as well as delivery time. Effectiveness considerations refer to profitability concerns: completing the project (meeting all specifications/objectives) with the least possible resource inputs, that is, the least costly input configuration. Such an “inter-local” strategy, although leading to the use of foreign resources, is not (directly) related to offshoring or even outsourcing. It falls rather under a classical efficient and effective procurement strategy.

At SNC-Lavalin, the offshoring per se began some six years ago. At that time, the firm, more precisely its Calgary based Chemicals and Petroleum division (headed by a CEO of Indian origin or descent), was very much involved in a multiphase bidding process for a major turnkey construction project in the Middle East. SNC-Lavalin's main competitor, late in the process, was a major South-East Asian firm (working closely with an engineering partner from India). 
In spite of having invested some 2M\$ in preparing its bid, SNC-Lavalin realized that it was on the verge of losing the project because of a cost disadvantage that it could not overcome, given that most of he engineering design work was expected to be done in Canada, or locally but by Canadian based engineers. At that time, the firm decided, in a bold move, to call in an Indian partner, to which a significant part of the engineering work could be delegated, allowing a sizable reduction in costs. SNC-Lavalin's final bid ended up being the winning bid and the project was realized to the client's satisfaction.

Following that experience with the Indian partner, in an arm's length relationship, and in spite of the successful collaboration between SNC-Lavalin and its Indian partner, the firm decided to search for firms it could eventually acquire. In 2005, the firm acquired RJ Associates (Engineers) Private Limited, a relatively small (150 engineers) engineering firm in Mumbai, India. It is now a fully owned subsidiary, which, thanks to a systematic and explicit Canada-India exchange programme for employees and executives, called to work on real on-going projects (on-the-job training, in a sense) in Canada, India or elsewhere, as well as the implementation of the firm's standardized internal processes and ICT base, is now completely integrated into SNC-Lavalin's culture, sharing the same vision and mission.

The decision acquire RJ Associates (Engineers) Private Limited rather than to extend the previous arm's length partnership was clearly made as part of a structural risk management two-prong strategy: first, opting for an "Intra-firm (captive) Offshoring” strategy rather than an "Offshore Outsourcing” strategy (Pyndt and Pedersen 2006); second, acquiring a relatively small company, which could be transformed into (trained) a full member of the SNC-Lavalin family. As expressed by Krish Krishnamoorthy, then CEO of the Chemicals and Petroleum division of SNC-Lavalin, "Otherwise, you always run into problems." Offshore outsourcing may be costly for continuity as engineering is cyclical and construction projects are very much dependent on a critical path sequencing value chain system (not simply a final procurement system). "Time is money, delays are costly; hence, we need a fine-tuned system to manage projects. Moreover, multiple sourcing in construction destroys trust.” 
The new SNC-Lavalin subsidiary in India is not simply providing engineering services for the Calgary based Chemicals and Petroleum division of SNC-Lavalin. It is providing such services as well for other divisions or centers of excellence of the company. More importantly, it is required to realize at least $50 \%$ of its revenues from (autonomous) local projects, serving both to ensure a proper return on investment and a form of benchmarking within the Indian offshoring services industry (competition at the agent's level generates valuable information for the principal). With the backing of SNC-Lavalin headquarters and the fruitful use of the SNC-Lavalin brand name, employment increased from 150 to 300 in the 18 months since the acquisition, with essentially the same local management team.

Clearly, SNC-Lavalin developed its offshoring strategy by experiencing first with an “Offshore Outsourcing” strategy, quickly put together because of the outside competitive pressure that it faced, precisely in its bid to win an important Middle East construction project about six years ago. Later, the strategy was refined into an "Intra-firm (captive) Offshoring” strategy with an added explicit (structural) risk management objective, itself a two-prong strategy: acquiring $100 \%$ of the targeted firm in order to be able to nurture it into a bona fide SNC-Lavalin subsidiary, and doing it in India because of its skilled human resources availability, both in number and quality, of its legal system ensuring not only the likely respect of contractual provisions but also proper protection for such a foreign direct investment, and of its "cultural proximity” as many Indian engineers and much of it skilled workforce have been trained in a Western, Western-like, or Western-friendly environment.

Another important factor that contributed to the design of an "Intra-firm (captive) Offshoring” preferred strategy is the domino effect. As leading firms in the industry are increasingly developing (cost cutting) offshoring strategies, a threat began emerging in recent years, namely the danger of being left behind in a non-competitiveness limbo. Indeed, following the success story that led to the acquisition RJ Associates (Engineers) Private Limited under the impetus of the Chemicals and Petroleum division, other divisions of SNC-Lavalin are assessing the experience and its relevancy for their own operations: hence the domino effect goes on both outside the firm and inside it. 
The entry of SNC-Lavalin in the offshoring movement came by chance and necessity rather than by strategic planning. Competitive pressures together with an emerging domino effect forced the first decision; structural risk assessment then led to the passage from "offshore outsourcing” to "offshore insourcing coupled with strong local incentives”, a strategic move that appears to be one more brilliant idea to the credit of SNC-Lavalin.

\section{Concluding Remarks}

The rise in services offshoring has been possible in large part because of ICT development and improvement allowing complex information to be exchanged and used around the world. Even if offshoring is first motivated by a cost reduction objective, other reasons push companies to transfer white collar tasks and jobs offshore. Important motives such as the expertise and the capacity as well as the flexibility provided by offshoring become increasingly relevant. Offshoring is thus a growing business and a potentially winning strategy for many firms.

Even if many predictions have been made concerning services offshoring, no one can exactly know how offshoring will affect the engineering, construction and infrastructure industry. For engineering companies such as SNC-Lavalin, the phenomenon of offshoring will probably change the way work is being performed although large engineering, construction and infrastructure firms are increasingly multinational and international, which means that their operations are discussed and planned without reference to notions of home country and foreign country. Engineers will necessarily be required to coordinate projects that have increasingly more global workforces and overseas networks. Local engineers could thus benefit by becoming familiar with other environments such as those in developing countries in order to maintain their competitiveness.

The SNC-Lavalin example we very briefly presented here, which is not necessarily symptomatic of the overall operations of the firm itself or of an explicit general strategy of 
the firm, provides some significant lessons for other firms and is suggestive of policy relevant implications.

First, an offshoring strategy must explicitly consider not only the cost reduction possibilities (often the igniting factor) to enhance competitiveness but also the risk management imperatives, not simply the financial risks involved but also the organizational risks, in particular the moral hazard and adverse selection risks. Of course, in this matter there is no single solution or strategy to fit all situations or business environments. But the success of the operation and sometimes the survival of the firm depend heavily on a proper assessment of the risk-adjusted profitability of an offshoring strategy.

Second, the designer of public policy alternatives towards the development of offshoring activities by Canadian firms should avoid the micro-management interventionist temptation that different interest groups may represent. Public policy should rather insist on developing and implementing (competitive, real option) market mechanisms and management processes that will ensure that firms are indeed making decisions towards global competitiveness in full knowledge of the risks but also the opportunities that an offshoring strategy might represent. One important but still largely unknown impact of the offshoring development is in terms of job creation, in the home country and the foreign country. By gaining in competitiveness, Canadian firms can create more (high valued) jobs here in Canada by offshoring some jobs abroad. Clearly, the SNC-Lavalin example above is such an example. Offshoring can be a win-win phenomenon. In fact, unless it is mismanaged, it will be such a win-win situation if the proper risk management tools, both for individuals and firms, are properly assessed, designed and implemented in order to favor the necessary adaptation, both at individual and firm levels, to a new world economic environment. Such should be the main if not the only objective of the offshoring related and relevant public policy compact. By any standard, this should be a difficult but exciting program. 


\section{References}

Boyer, M. (2005), "Comments on Public Policy Support for Innovation and Commercialization in Canada”, mimeo, 28 pages.

http://www2.cirano.qc.ca/ boyerm/fr/doc_recents/Commercialization-2.pdf

Boyer, M. (2007), The Competitive Social Democracy Modela nd Project: A New Development Model for Québec, Canada and More (forthcoming).

Brown, D. and Wilson, S. (2005), The Black Book of Outsourcing: How to Mange the Changes, Challenges, and Opportunities, Wiley.

Cohen, L. and Young, A. (2006), Multisourcing: Moving Beyond Outsourcing to Achieve Growth and Agility, Harvard Business School Press.

Dossani, R. and Kenney, M. (2004), “The Next Wave of Globalization? Exploring the Relocation of Service Provision to India," Berkeley Roundtable on the International Economy, WP \#156.

Hart, O. (1983), «The Market as an Incentive Mechanism,» Bell Journal of Economics 14, 366-382.

Hermalin, B. (1992), «The Effects of Competition on Executive Behavior,» Rand Journal of Economics 23, 350-365.

Hermalin, B. (1994), «Heterogeneity in organizational Form: Why Otherwise Identical Firms Choose Different Incentives for their Managers,» Rand Journal of Economics 25, 518-537.

Holmström, B. (1982), «Moral Hazard in Teams,» Bell Journal of Economics 13, 392-415.

Industry Canada Roundtable on Offshoring (2005).

Laffont, J.J. and Tirole, J. (1993), A Theory of Incentives in Procurement and Regulation, MIT Press, Cambridge.

Leibenstein, H. (1996), «Allocative Efficiency vs. 'X-Efficiency',» American Economic Review 56, 392-415.

LeGallo, V. (1998), «Compulsory Competitive Tendering: The U.K. Experience,» mimeo, CIRANO (Montreal).

Machlup, F (1967), «Theories of the Firm: Marginalist, Behavioral, Managerial,» American Economic Review 57, 1-33. 
Nalebuff, B. and Stiglitz, J. (1983), «Information, Competition, and Markets,» American Economic Review, Papers and Proceedings 73, 278-283.

neoIT Inc. (2004), The Services Globalization Handbook, San Ramon, CA.

Pyndt, J. and Pedersen, T. (2006), Managing Global Offshoring Strategies - A Case Approach, Copenhagen Business School Press.

Robinson, M. and Kalakota, R. (2005), Offshore Outsourcing: Business Models, ROI and Best Practices, $2^{\text {nd }}$ edition, Mivar Press Inc.

Scharfstein, D. (1988), «Product Market Competition and Managerial Slack,» Rand Journal of Economics 19, 147-155.

Shleifer, A (1985), «A Theory of Yardstick Competition,» Rand Journal of Economics 16, 319-327.

Schmidt, K. (1997), «Managerial Incentives and Product Market Competition,» Review of Economic Studies 64, 191-213.

Vashistha, A. and Vashistha, A. (2006), The Offshore Nation: Strategies for Success in Global Outsourcing and Offshoring, McGraw-Hill. 